\title{
BENTUK POLA PUKULAN KELUHKUPAN \\ PADA MASYARAKAT SUKU DAYA MUARADUA OKU SELATAN
}

\author{
Auzy Madona Adoma ${ }^{1)}$ \\ Email: auzymadonaadoma@ymail.com
}

\begin{abstract}
Keluhkupan is a traditional tool used by the Daya tribe as the conveyor of information by using the main wood (keluhkupan) and stick (helu) which are hit with hard blows that have different rhythmic patterns from the signs of disaster that exist in each wasp of complaints. among them are fatalities, natural disasters and riots. The three strokes have different sound patterns from dynamics, tempo and rhythm. The people who are believed to beat Keluhkupan are only allowed to be traditional leaders (men only) and those who beat Keluhkupan must really know how the sound patterns of Negu Death, Negu Sasah Bencana and Negu Sasah Huru-hara sound patterns. Negu Death is carried out when a villager dies, traditional leaders beat Keluhkupan from soft to stronger with punches from slowly to faster. Negu Sasah This wasp disaster is carried out if there is a disaster tokah adat hitting Keluhkupan powerfully and quickly. Negu Sasah This wasp riot is a sign that there has been a fight between the traditional leaders hitting Keluhkupan quickly and strongly, indicating haste or Kesasah.
\end{abstract}

Keywords: Keluhkupan, Wasp Pattern, Characteristics of Wasp

\begin{abstract}
Abstrak
Keluhkupan merupakan suatu alat tradisi yang digunakan masyarakat suku Daya sebagai penyampai informasi dengan menggunakan kayu utama (keluhkupan) dan tongkat (helu) yang dipukulkan dengan pukulan pukulan keras yang memiliki pola-pola irama berbeda dari tanda-tanda musibah yang ada pada tiap pukulan keluhkupan, diantaranya adalah musibah kematian, bencana alam dan huruhara. Adapun ketiga pukulan ini memiliki pola bunyi yang berbeda baik dari dinamika, tempo dan ritme. Masyarakat yang dipercaya untuk memukul Keluhkupan hanya diperbolehkan adalah tokoh adat (laki-laki saja) serta yang menabuh Keluhkupan harus benar-benar mengetahui bagaimana bentuk pola-pola bunyi pukulan Negu Kematian, Negu Sasah Bencana dan Negu Sasah Huru-hara. Negu Kematian dilakukan bila ada masyarakat desa yang meninggal dunia, tokoh adat memukul Keluhkupan dari lembut hingga semakin kuat dengan pukulan dari perlahan hingga semakin cepat. Negu Sasah Bencana pukulan ini dilakukan jika ada bencana tokah adat memukul Keluhkupan dengan kuat dan cepat. Negu Sasah Huru-hara pukulan ini sebagai isyarat bahwa telah terjadi perkelahian tokoh adat memukul Keluhkupan dengan cepat dan kuat yang menandakan tergesah-gesah atau Kesasah.
\end{abstract}

Kata Kunci : Keluhkupan, Pola Pukulan, Ciri-ciri Pukulan 


\section{Pendahuluan}

Budaya atau kebudayaan berasal dari bahasa sansekerta "budhayah", yaitu bentuk jamak dari budhi yang berarti "budi" atau "akal". Sedangkan kata "budaya" merupakan perkembangan majemuk dari "budi daya" yang berarti "daya dari budi" yang berupa cipta, karsa dan rasa. (Koentjaraningrat dalam Sudartati, 2010:4).

Dengan demikian kebudayaan merupakan halhal yang bersangkutan dengan akal. Kebudayaan dapat diartikan sebagai keseluruhan pengetahuan, kepercayaan, nilai-nilai yang dimiliki oleh manusia dan disebarluaskan secara turun menurun melalui proses belajar (Sugiyanto, 2011: 1).

Kesenian merupakan bagian dari kebudayaan, seni pada dasarnya melibatkan emosional baik antara individu atau berkelompok yang saling mendukung dan membutuhkan akan suatu estetika dalam kehidupan. Kesenian merupakan unsur pengikat yang mempersatukan pedoman-pedoman yang bertindak yang berbeda menjadi suatu desain yang utuh, menyeluruh dan operasional, serta dapat diterima sebagai sesuatu yang bernilai. Noryan (dalam Sartono, 2014:2).

Sumatera Selatan merupakan salah satu Provinsi di Indonesia yang sering disebut daerah Batang Hari Sembilan, disebut Batang Hari Sembilan sebab didaerah ini terdapat sembilan sungai besar dan berpuluh-puluh anak sungai yang dapat dilayari dengan kapal-kapal maupun rakit.

Antara manusia dan kebudayaan terjalin hubungan yang sangat erat, karena menjadi manusia tidak lain adalah merupakan bagian dari hasil kebudayaan itu sendiri. Kecuali tindakan yang sifatnya (Animal Instinct). Tindakan yang berupa kebudayaan tersebut dibiasakan dengan belajar, seperti melalui proses internalisasi, sosialisasi, dan alkulturasi. (Rusmin Tumanggor, 2010:17).

Terdapat banyak kesenian-kesenian tradisional di Sumatera Selatan khususnya "Kabupaten Ogan Komering Ulu Selatan" salah satunya adalah kesenian Keluhkupan yang berada di Suku Daya Muaradua OKU Selatan. Keluhkupan merupakan salah satu bentuk alat musik dari daerah Suku Daya Shiburan, pada umumnya Keluhkupan ini digunakan sebagai penyampai informasi, ada dua jenis pukulan atau negu pada Keluhkupan yaitu Negu Kematian atau meninggal dunia dan NeguSsasah.

Negu Kematian Menurut Hajmi Arsul (sumber: wawancara) Negu adalah cara dari tokoh adat untuk memukul Keluhkupan sehingga menghasilkan bunyi yang menandakan suatu peristiwa, sedangkan kematian merupakan akhir dari kehidupan manusia. Sehingga dapat dipahami bahwa Negu Kematian adalah suatu tanda yang menyampaikan informasi bahwa terdapat warga desa setempat yang telah meninggal dunia. Negu Sasah adalah pukulan yang tergesah-gesah untuk menyampaikan informasi bahwa suatu desa ada bencana musibah seperti kebakaran gempa dan bencana lainnya atau huruhara seperti peperangan dan perkelahian yang diharapkan masyarakat segera datang untuk memberikan pertolongan. Negu Sasah Bencana merupakan suatu tanda berita bahwa telah terjadinya bencana alam seperti kebakaran, gempa dan banjir sehingga tokoh adat Negu Keluhkupan atau Nabuh Keluhkupan sebagai penanda bahwa telah terjadinya bencana. Negu Sasah Huruhara (Perkelahian/Peperangan) merupakan suatu tanda yang disampaikan bahwa telah terjadi perkelahian atau perperangan yang terjadi didesa setempat. Namun tidak jarang ada kekeliruan pada saat tokoh adat menabuh atau Negu Musibah atau Huruhara karena hampir mempunyai kemiripan pada bunyi, berbeda dengan Negu Kematian.

Perkembangan kehidupan budaya, baik fisik maupun non fisik diikuti pula dengan munculnya berbagai tradisi lokal. Perkembangan tradisi lokal ini yang sudah ada pada zaman dahulu perlahan-lahan menghilang akibat pola kehidupan masyarakat yang semakin maju dan sudah banyak alat-alat canggih yang dapat digunakan untuk menyampaikan informasi sehingga masyarakat Suku Daya sendiri tidak banyak yang mengetahui pola-pola bunyi pada pukulan Keluhkupan itu sendiri. Bedasarkan fenomena permasalah tersebut maka peneliti tertarik untuk melakukan penelitian dengan judul "Bentuk Pola Pukulan Keluhkupan Pada Masyarakat Suku Daya Muaradua OKU Selatan”

\section{A. Metode Penelitian}

Secara umum metode penelitian dapat diartikan sebagai cara ilmiah untuk mendapat data dengan tujuan dan kegunaan tertentu. Metode penelitian adalah cara yang digunakan oleh peneliti dalam mengumpulkan data penelitiannya (Arikunto, 2010:203). Penelitian ini akan memberikan gambaran secara sistematis mengenai pola ritme Keluhkupan untuk menyampaikan informasi pada masyarakat Suku Daya Muaradua OKU Selatan. Adapun metode penelitian yang digunakan adalah deskriptif kualitatif.

Metode kualitatif adalah metode yang lebih menekankan pada aspek pemahaman secara mendalam terhadap suatu masalah daripada melihat permasalahan untuk penelitian generalisasi. Deskriptif kualitatif data yang dikumpulkan adalah berupa kata-kata, gambar, dan bukan angka-angka. Dengan demikian laporan akhir akan berisi kutipan-kutipan data untuk memberikan gambaran penyajian laporan tersebut. Data tersebut bisa saja dari naskah wawancara, foto catatan lapangan, dokumen pribadi ataupun dokumen resmi lainnya (Moleong, 2010:11).

Dari pendapat diatas, penelitian ini memakai jenis metode penelitian kualitatif yang dirasa sangat cocok karena penelitian kualitatif merupakan penelitian yang digunakan apabila faktor penelitian tidak dapat dikuantifikasikan atau tidak dapat dihitung sehingga variabel tidak dapat diungkapkan dengan angka seperti persepsi, pendapat, anggapan dan sebagainya.

Menurut Sutrisno Hadi (dalam Sugiyono, 2010: 203) mengemukakan bahwa observasi merupakan suatu proses yang kompleks, suatu proses yang tersusun dari berbagai proses biologis dan psikologis. Dua diantara 
yang terpenting adalah proses-proses pengamatan dan ingatan.

(Moleong, 2010:175) penggunaan pengamatan ialah: pengamatan mengoptimalkan kemampuan peneliti dari segi motif, kepercayaan, perhatian perilaku tak sadar, kebiasaan dan sebagainya. Pengamatan memungkinkan pengamat utuk melihat dunia sebagaimana dilihat oleh sabjek penelitian, hidup pada saat itu, menangkap arti fenomena dari segi pengertian subjek, menangkap kehidupan budaya dari segi pandangan dan anutan para subjek pada keadaan waktu itu.

Dari uraian diatas dapat disimpulkan bahwa observasi atau pengamatan dapat dikatakan sebagai kegiatan dalam bentuk penerimaan data melalui alat panca indra dengan cara mencatat, mendengarkan, melihat kejadian yang akan diteliti seperti pengamatan pada pola ritme Keluhkupan sebagai penyampai informasi musibah pada masyarakat Suku Daya Muaradua OKU Selatan. Keluhkupan memiliki tiga pukulan sebagai bentuk dari penyampai informasi yang ketiganya memiliki masing-masing pola atau bentuk uraian kejadian untuk melakukan pemukulan hingga bunyi yang dihasilkan dari ketiga aspek tersebut.

1. Negu Kematian yang dilakukan pada saat tejadinya bila ada masyarakat desa yang meninggal dunia. Tokoh adat mendapatkan informasi dari warga desa supaya Negu atau Tabuh Keluhkupan, dari hasil observasi tokoh adat memukul Keluhkupan dari lembut hingga semakin kuat dengan pukulan dari perlahan hingga semakin cepat.

2. Negu Sasah Bencana, Negu atau pukulan ini dilakukan jika ada bencana misalkan terjadi bencana kebakaran, gempa, badai dan sebagainya. Pada saat terjadi bencana didesa baik mengetahui lebih awal atau diberi tahu tokoh memukul Keluhkupan dengan kuat dan cepat.

3. Negu Sasah Huru-hara, Negu atau pukulan ini hampir menyerupai suara pukulan musibah, namun informasi yang disampaikan jauh berbeda. Pukulan ini sebagai isyarat bahwa telah terjadi perkelahian atau peperangan, sama halnya dengan pukulan pada Negu Sasah Musibah, tokoh adat memukul Keluhkupan dengan cepat dan kuat yang menandakan tergesahgesah atau Kesasah.

Dari ketiga aspek diatas peneliti akan meneliti bagaimana dinamika, tempo dan ritme yang terdapat pada pukulan Keluhkupan tersebut.

\section{Pembahasan}

Keluhkupan adalah salah satu alat tradisi masyarakat Suku Daya OKU Selatan, dan juga beberapa desa yang msih menggunakan Keluhkupan tersebut, Keluhkupan ini berbahan kayu memiliki ukuran yang sangat besar berbentuk bulat panjang 2-3 meter berdiameter lebih dari $60 \mathrm{~cm}$ bahkan ada yang lebih dan memiliki lobang dibagian tengahnya dan Helu adalah sebagai alat pemukul dari Keluhkupan yang yang berukuran panjang 2 meter dan biasanya Helu digunakan oleh masyarakat setempat sebagai penumbuk padi.
Kebiasaan Suku Daya setempat menggunakan Negu (menabuh atau memukul) Keluhkupan hanya pada 3 hal kejadian saja yaitu ada msyarakat yang meninggal dunia, dan pukulan atau Negu Sasah (tergesah-gesah) Negu Sasah Bencana dan Negu Huruhara.



Gambar 1. Keluhkupa (Dokumentasi Jefri)

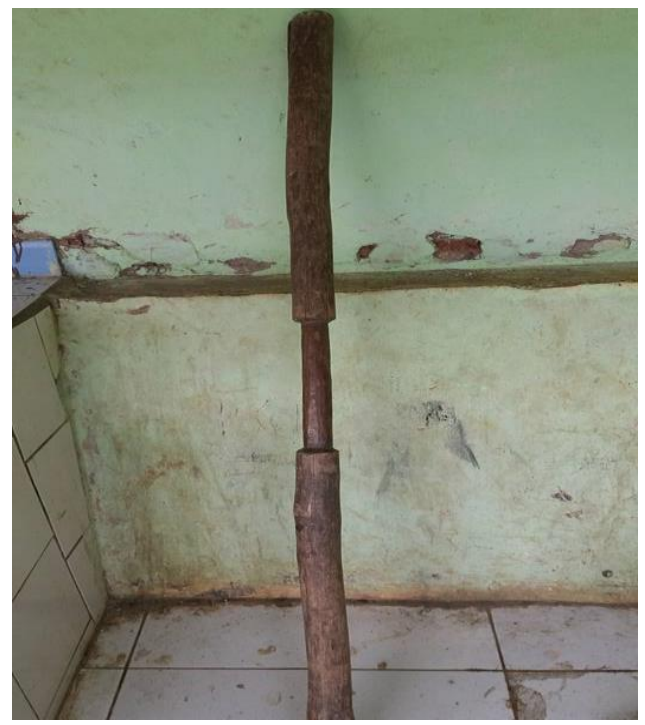

Gambar 2. Helu (Dokumentasi Jefri)

Pola ritme Keluhkupan merupakan pukulan sebagai tanda penyampai informasi musibah terhadap masyarakat Suku Daya, Keluhkupan hanya memiliki tiga jenis pukulan yang menyampaikan tanda berita musibah kematian, bencana atau huru-hara. Adapun ketiga pukulan ini memiliki pola bunyi yang berbeda baik dari dinamika, tempo dan ritme. Bunyi Keluhkupan yang dipukulkan tidak sembarang masyarakat melakukan karena hanya diperbolehkan laki-laki dan dipercaya masyarakat desa karena itu tokoh adat yang menabuh Keluhkupan harus benar-benar mengetahui bagaimana bentuk pola-pola bunyi pukulan Negu Musibah kematian 
Negu Sasah Bencana atau Negu Sasah Huru-hara berikut adalah pola ritme Keluhkupan

1. Negu Musibah Kematian

Negu Kematian yang dilakukan pada saat tejadinya bila ada masyarakat desa yang meninggal dunia. dari hasil penel observasi tokoh adat memukul Keluhkupan dari lembut hingga semakin kuat dengan pukulan dari perlahan hingga semakin cepat seperti berikut:
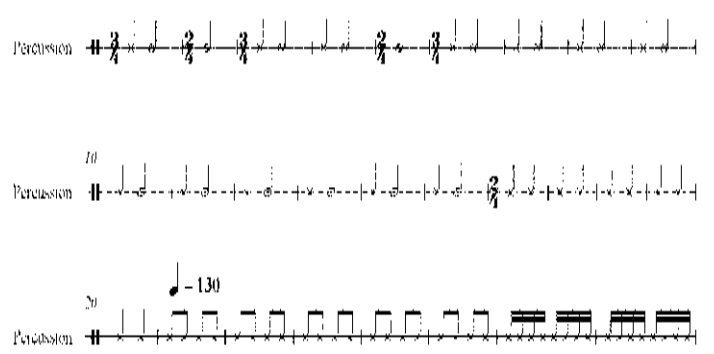

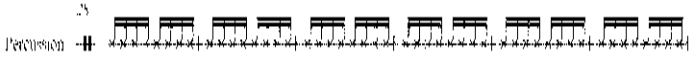
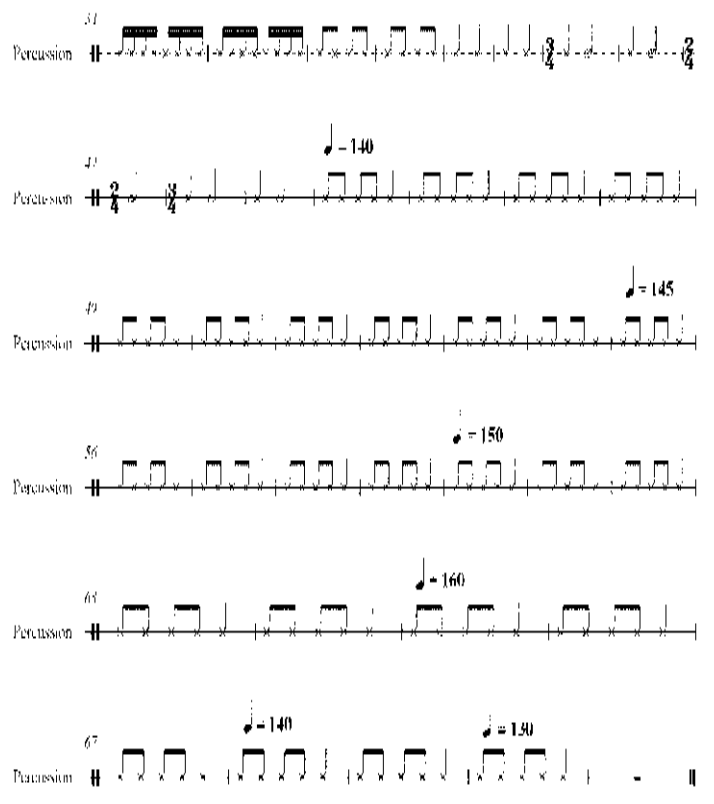

Dalam bentuk notasi diatas terhitung satu pukulan pada negu kematian, dalam pukulan dimulai dari pukulan pertama seperti notasi di atas yang terhitung satu pukulan dan seterusnya dihitung hinga pukulan ter akhir yang jumlahnya bisa genap, dan ganjil yang berarti pukulan genap adalah perempuan jumlah pukulan dari $4,6,8,10,12,14$. Sebaliknya jika laki-laki maka pukulan ganjil jumlah pukulan dimulai dari 3,5,7,9,11,13,15. Masyarakat akan merespon bunyi keluhkupan dengan menghitun berapakali pukulan yang ditabuh oleh tokoh adat desa, jika pukulan tidak terlalu lama antara 3,4,5,6,7,dan 8 berarti ada masyarakat desa meninggal dunia yang masih muda juga demikian sebaliknya pukulan yang di atas 9,10,11,12,13,14 dan 15 berarti ada masyarakat yang sudah lanjut usia meninggal dunia.
Maka jika ada pukulan keluhkupan masyarakat akan bergegas mencari atau pulang dari ladang (huma) untuk menuju rumah duka membantu dan menghibur keluarga yang berduka.

\section{Negu Sasah Bencana}

Negu Sasah Bencana, Negu atau pukulan ini dilakukan jika ada bencana misalkan terjadi bencana kebakaran, gempa, badai dan sebagainya. Pada saat terjadi bencana didesa baik mengetahui lebih awal atau diberi tahu tokoh memukul Keluhkupan dengan kuat dan cepat.
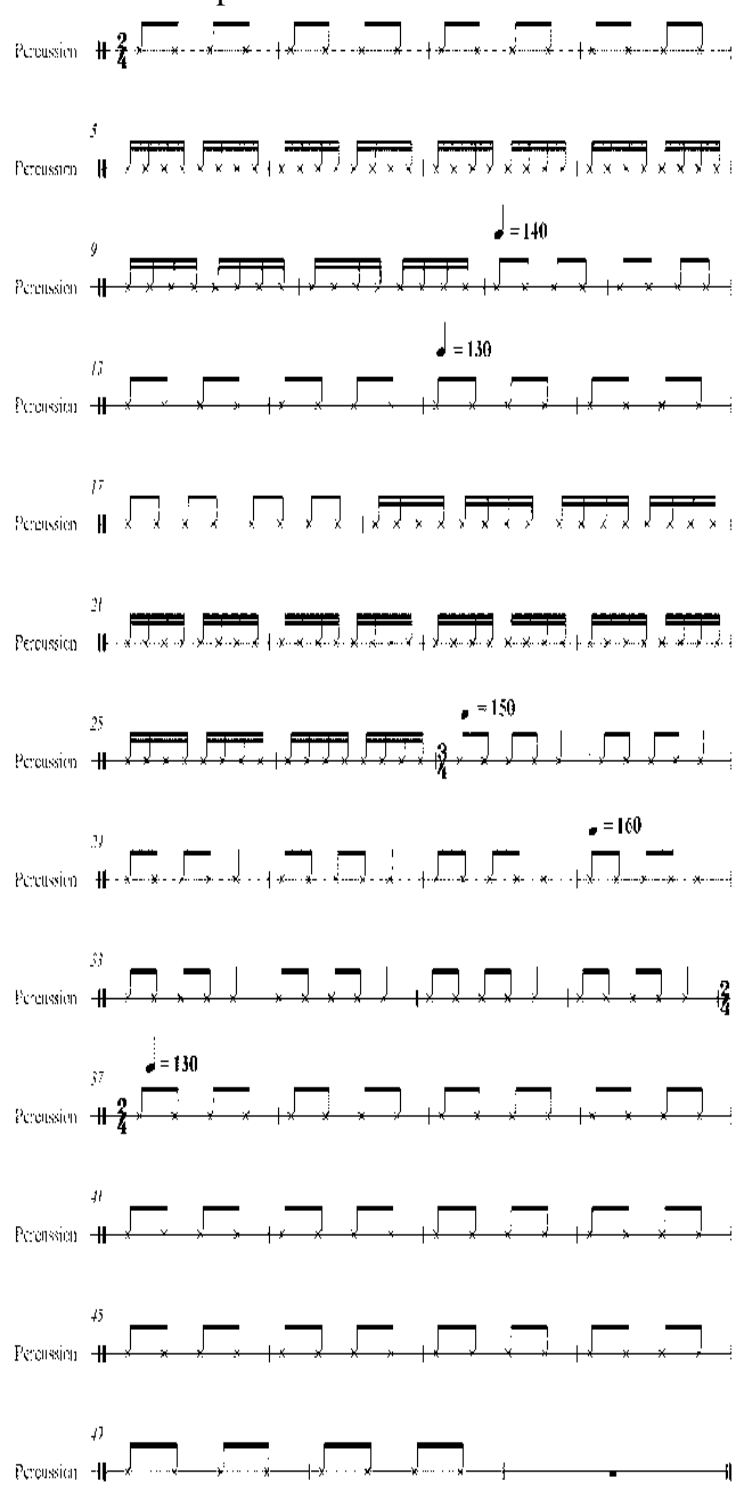

Pada pola pukulan kebakaran diatas dipukul secara cepat dan memiliki kesan tergesa-gesa yang menyampaikan bahwa adanya musibah yang ada di daerah setempat, pukulan ini tidak mementingkan bagaimana bentuk polanya karena bisa berubah-ubah dan acak tidak beraturan. Masyarakat akan cepat merespon pukulan ini jika terdengar karna bisa membahayakan selruh masyarakat, jika terjadi kebakaran masyarakat desa bergotong-royong memedamkan api jika ada gempa bumi masyarakat akan berkumpul dihalaman yang luas. 3. Negu Sasah Huru-hara, 
$\mathrm{Negu}$ atau pukulan ini hampir menyerupai suara pukulan musibah, namun informasi yang disampaikan jauh berbeda. Pukulan ini sebagai isyarat bahwa telah terjadi perkelahian atau peperangan, sama halnya dengan pukulan pada Negu Sasah Musibah, tokoh adat memukul Keluhkupan dengan cepat dan kuat yang menandakan tergesah-gesah atau Kesasa

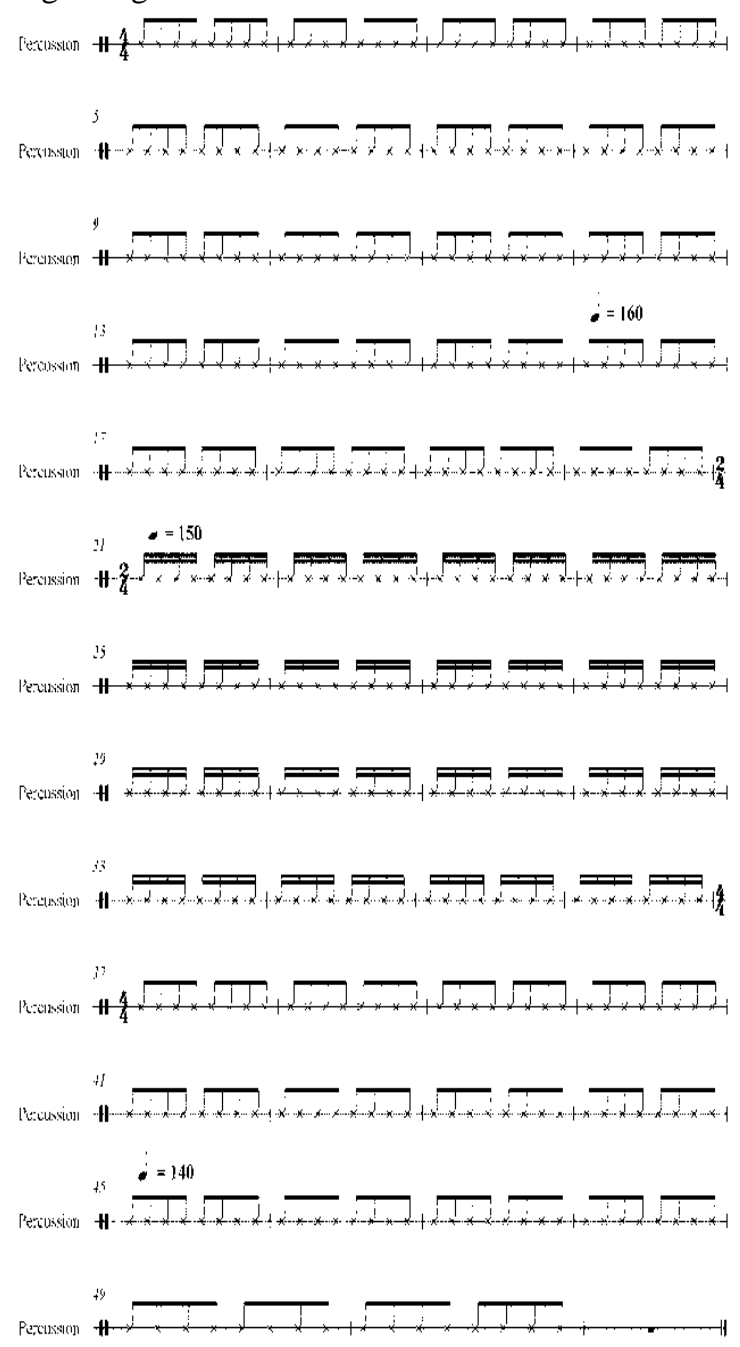

Pada pola diatas hampir menyerupai pukulan Negu Sasah Kebakaran yang mementingkan kesan tergesah-gesah namun yang beda dari pukulan Negu Sasah Huru-hara adalah dipukul secara ber urutan dan tidak acak.

\section{Kesimpulan}

Keluhkupan merupakan suatu alat tradisi yang digunakan masyarakat suku Daya sebagai penyampai informasi dengan menggunakan kayu utama (keluhkupan) dan tongkat (helu) yang dipukulkan dengan pukulan pukulan keras yang memiliki pola-pola irama berbeda dari 3 tanda musibah yang ada pada tiap pukulan keluhkupan, diantaranya jika terjadi musibah kematian, bencana alam dan huruhara. Pola ritme yang didengar oleh masyarakat umumnya hanya pukulan meninggal dunia dan bencana alam atau kebakaran saja. Jika masyarakat desa mendengar pukulan keluhkupan berarti masyarakat harus segera pulang dari kebun atau sawah untuk berkumpul memenuhi panggilan keluhkupan yang ditabuh oleh tokoh adat yang telah ditentukan masyarakat.

Berdasarkan hasil penelitian dapat di simpulkan bahwa pola ritme pada bunyi keluhkupan tidak seluruh masyarakat masih mengetahui hanya pukulan kematian saja yang masih dapat di mengerti dan mereka tidak banyak mengerti secara jelas siapa apakah laki-laki atau perempuan yang meninggal dunia. Pada pukulan kematian pukulan yang di ulang-ulang hingga pada hitungan yang tepat membuat sebagian masyarakat kurang mengerti dan di iringi kemajuan teknologi membuatmasyarakat ebih cepat mengetahui di bandingkan mendengarkan bunyi pukulan keluhkupan. Pada pukulan sasah masyarat cenderung mengetahui jika ada terjadi kebakaran saja di bandingkan pukulan sasah huruhara karena masyarakat sekarang belum pernah mendengar pukulan sassah huru-hara namun hanya tokoh adat yang mengetahui berdasarkan cerita dan ajaran dari tokoh adat terdahulu secara turun temurun.

\section{Daftar Pustaka}

Arikunto. 2010. Prosedur Penelitian (Cetakan Keempat Belas). Jakarta: Rineka cipta.

Agustianto. 2013. Solfegio 1. Yogyakarta: Jurusan Pendidikan Seni Musik Fakultas Bahasa dan Seni.

Bell (1939). Filsafat Seni. ITB. 2011:58. Bandung.

Basrowi, dkk. 2008. Memahami Penelitian Kualitatif. Jakarta: PT Rineka Cipta.

Harsojo. (1984: 223). Pengantar Antropologi. Bina Cipta. Bandung.

Kamaril, C dkk. (1998: 15). Pendidikan Seni Rupa dan Kerajinan Tangan. Depdikbud. Jakarta.

Read. (1959:1). Kritik Seni. Rekayasa Sains. Bandung.

Setiadi, Elly. 2011. Ilmu sosial budaya dasar (cetakan ketujuh). Jakarta peranada media grup

Supardan. 2007. Pengantar Ilmu Sosial. Bandung: Bumi Aksara

Soerjono, 2007. Sosiologi Suatu Pengantar, PT Raja Grafindo: Jakarta.

Sakri. (1990: 11). Pendidikan Seni Rupa.

Depdikbud. Jakarta.

Soerjono, 2003. Sosiologi Suatu Pengantar. Penerbit PT Raja Grafindo Persada : Jakarta.

Sugiyono. 2010. Memahami Penelitian Kualitatif. Bandung: Alfabeta.

Sugiyono. 2010. Metode Penelitian Pendidikan. Bandung: Alfabeta.

Sukerta, Pande Made, "Metode Penyusunan Karya Musik (Sebuah Alternatif)", ISI Press Solo, Solo, 2011.

Supanggah, Rahayu. "Garap: Salah Satu Konsep Pendekatan / Kajian Musik Nusantara”, dalam Waridi, ed. Menimbang Pendekatan Pengkajian dan Penciptaan Musik Nusantara. Surakarta: 
Jurusan Karawitan \& STSI Press, Surakarta, 2005.

Tumanggor, Rusmin. 2010. Ilmu Sosial \& Budaya dasar. Kencana : Pernada Media Group.

Wignjodipoero. 1995. Pengantar dan Asas-Asas Hukum Adat. Jakarta: Toko Gunung Agung.

Tumanggor, Rusmin. 2010. Ilmu Sosial \& Budaya dasar. Kencana : Pernada Media Group. 